normal; pulse 100. Wound dressed. Pus smelling pecuIiarly.-5th: Temperature normal; pulse 100 . Wound dressed. It is now evident that there is a communication between the intestine and the abscess cavity, as the discharge is mixed with fæces.-6th: Temperature normal; pulse 112. Patient excited and frightened, because she has felt while straining at stool that a good deal of freal matter comes by a tube and none by the anus. Wound dressed.-7th: Temperature $99.5^{\circ}$; pulse 114 . The patient feels very well, and is not alarmed, as she has passed three motions by the anus and very little by the wound. Since the first passage of the fæcal matter by the tube the abdominal wound is carefully protected by an arrangement of mackintosh and adhesive plaster, and the attendant constantly renews the dressing around the mouth of the tube; also the abscess cavity is frequently syringed out with carbolic lotion.-12th: Temperature and pulse normal. Wound dressed; almost no discharge. Continuous suture removed. The abdominal incision is firm] y healed. The patient eats and sleeps well.-21st: Drainagetube removed. Cavity quite contracted. Patient sitting up in bed.

The woman went home restored to health on May 31st. Menstruation returned at the end of July and continued regular. A year after the operation I was told that the patient continued to enjoy perfect health.

Remarks. - That this case is an example of suppurating hromatoma I think there can be little doubt; but a special interest is added by the communication, which occurred on the fourth day after operation, between the bowel and the abscess cavity. It is probable that we have here an illustration of the course of such abscesses as described by Dr. West, who says: "When suppuration takes place, the matter makes its way outwardly through the vagina or through the intestinal canal in almost all cases in which the inflammation is limited to the parts contained within the broad ligament." From the length of the illness, which lasted six months, it seems probable that the pus had begun to seek an outlet towards the bowel. On evacuating the abscess, the weakened part of the intestinal wall would yield towards the cavity, and finally give way when the patient strained at stool. No pus wes at any time observed in the motions. The rapid progress toward complete recovery did not appear to be delayed by the complication which occurred.

fluelva, Spain.

\section{CYST OF THE GREAT OMENTUM. REMOVAL, RECOVERT.}

By J. C. GOODING, M.D.

MIss - - in 1878, when aged eighteen years, first noticed a lump the size of a hen's egg low down in the right iliac region, which, at the monthly periods chiefly, was painful. It gradually enlarged upwards till, at the time of my first visit in August, 1879, it had attained the size of a cocoa-nut and reached two inches above and to the left of the umbilicus, and three inches below, extending back into the lumbar region. It was elastic, could be completely pushed across the abdomen to the left of the umbilicus, and pressed down to Poupart's ligament; there was most dimitation to upward movement, and between it and the liver there was resonance. My first impression was that it was a renal growth, but the tumour could be moved away from the kidney without le lving any sense of void in the loin; it was freely movable in all directions, but less so from the ovarian site. The urine was healthy, and there was no constitutional disturbance. I diagnosed ovarian cyst with long pedicle. In March, 1880, the patient at my request saw Sir S. Wells, who wrote me that his impression was it was renal, but, having doubt, wished Sir W. Jenner to see the case with him, which he did a few days afterwards. The result of the consultation was that they both, "while doubting, inclined rather to the view of an ovarian tumour with a long pedicle than a renal cyst cr tumour," and both agreed in advising, "in the absence of any urgent symptoms, no surgical interference."

During the summer of 1881 the patient began to suffer from sickness and occasional vomiting after meals, and a great deal of shooting and aching pain in and about the tumour. These symptoms much impaired her health; and interference, for which the patient was anxious, was determined on. The growth had now attained the size of a child's head of four years old, had equally enlarged without altering its relation to other parts, was as mobile as ever, and obviously contained fluid.

On $\Lambda$ pril 27 th, 1882, Mr. Cardew gave ether and Mr. C. J. Newton assisted me. When the patient was anæsthetised the tumour retreated so much under the hypochondrium that it was obviously not ovarian (a confirmation of the value of anæsthetics for abdominal diagnosis-so well known, but so seldom employed), a short incision into the peritoneal cavity, confirming this, was extended to the umbilicus, and disclosed a white cyst covered by peritoneum; this was scratched through so as to admit the finger, which was swept round, breaking down strong areolar tissue. On seizing the tumour with a vulsellum a clear fluid gushed out; then a most tedious process of separation, facilitated by holding the thin-walled cyst up against the light, was effected by scratching through dense cellular tissue, its closely fitting envelope. There was no pedicle, the tumour was embedded in folds of the omentum, having the transverse colon immediately below it. There was no hæmorrhage. The entire operation was conducted under carbolic acid spray-a practice, however, which I no longer follow.

The patient, very pallid and cold, but with fair pulse (60), was removed to bed, and after a couple of hours the extremities became warm. During the first night there was much pain referred to the left shoulder and back. For thirty-six hours there was continuous sickness. On the second day the temperature was $100^{\circ}$ and the pulse 98-104. Barley-water and milk in small quantity were relished and retained. On the third day the temperature was natural, and the pulse 92. On the seventh day three sutures were remored, and the remainder on the tenth day; firm union had taken place. The progress to recovery continued uninterrupted, and the patient, when last seen (September, 18R3) was enjoying good health.

The tumour much resembled an hydatid cyst, but it was not of this nature. Its origin (obscure) might have been due to a severe blow in the abdomen sustained some months before. Cheltenham.

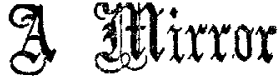

of

\section{HOSPITAL PRACTICE, BRITISH AND FOREIGN.}

Fulla autem est alia pro certo noscendi via, nisl quamplurimas ef morborum et dissectionum historias, tum aliorum tum proprias collectas habere, et inter se comparare.-MonGAGNI De Sed. et Caus. Morb., habere, et inter so
lib. iv. Procemium.

ST. MARY'S HOSPITAL.

PARTIAL ENTEROCELE; GANGRENE; RECOVERY; REMARKS. (Under the care of Mr. EDMrund OwEN.)

THE term here used to describe the hernia which was the cause of the symptoms in the following case is one which will probably find general acceptance. If our readers will refer to the report of the meetings at which the papers referred to (vide infra and page 314) were discussed, they will gain much information on the subject of this form of protrusion.

On November 30th, 1886, a spare man, aged fifty-seven years, was admitted with a strangulated femoral hernia on the left side, of the size of a large walnut. He vomited a good deal, but the ejecta had no stercoraceous odour; there was no tympanites and no hiccorigl, but the man was somewhat collapsed. He said that the hernia had been down generally during the past three winters, when his cough was bad, but that nearly the whole of it went away when the mild weather arrived; that there was, however, at the best of times, al ways a very smsall piece which did not go back. He said further that the hernia, in the larger mass, had been down for nearly a week, that for five days his bowels had not acted, and during that time he had been frequently sick, and in pain across the umbilicus. Without any difficulty Mr. Lloyd, the house-surgeon, returned the 